\title{
TRAINING OF STUDENT NURSES
}

\author{
BY \\ A. BARR \\ Oxford Regional Hospital Board
}

The urgent need to minimize wastage among student nurses during training is too well known and well documented to require elaboration. Approximately one student out of every three joining the training schools of general hospitals fails to complete the prescribed course. The reasons for this failure vary, but are generally vague and indefinite. One approach to the problem is to compare the characteristics of those students who are successful in the final of the state registration examination with those who failed and/or left training before qualifying. In this way it may be possible to isolate factors related to the ultimate result of training.

The Oxford Area Nurse Training Committee, in conjunction with the Oxford Regional Hospital Board, is currently surveying four training schools in the region, and a preliminary report on the results has been published (Barr, James, and Smith, 1957). The purpose of the present paper is to record additional information and, in particular, to compare the successful and unsuccessful groups of students.

\section{Methods AND Material}

The survey methods used and the material collected have been described elsewhere (Barr and others, 1957), but for convenience a brief summary is given. The survey includes all students joining four general hospitals during the years 1951 to 1954 inclusive. For the present paper, however, use is made of the data relating to the years 1951 to 1953 only, because various amendments were made to the syllabus of the General Nursing Council on January 1, 1954. A questionnaire (in the form of a Copeland Chatterson punch card) was devised to note such facts as year of joining, age, marital status, school-leaving age, social class of parents, etc. One card was completed by the matron for each student joining the training school during the survey period, and each student will be followed up for a minimum period of 4 years.

The hospital training schools were chosen to be as unlike as possible. It was hoped that the results would then be representative, to some extent, of the region as a whole. The number of related beds per hospital ranged from just over 100 to nearly 800 and the number of students per school enrolled during the 4 years ranged from 81 to 506. In all, 1,564 beds and 925 students are included in the survey. The theoretical maximum number of students for the 4 years was 1,149 , so that in total the training schools were 81 per cent. full.

The following information is available for each student, at each of the four training schools surveyed, by each of the three intake years (1951-1953) with which this analysis is concerned:

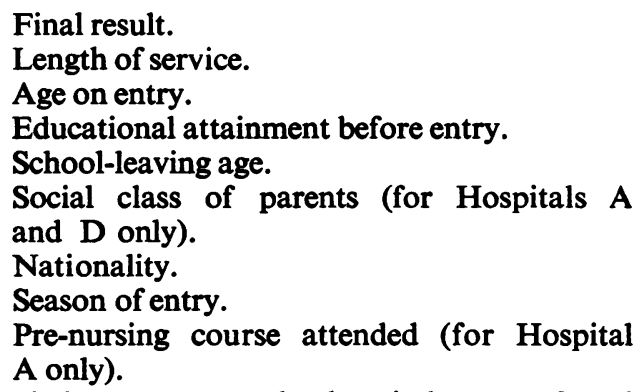

For obvious reasons, the hospitals are referred to anonymously.

\section{STUDENT GRouPS}

As already indicated, the students are considered in two broad groups: (a) successful and (b) unsuccessful. Group (a) includes all students who passed the final of the state examination irrespective of whether they remained at the hospital or not after qualifying. Group (b) consists mainly of those 
students who left with no qualifications or those who left with Parts I and II of the state examination. There were a few students in this group who were still at the hospital at the date of the analysis. It is possible that some of these students may qualify eventually, though each has already had a reasonable time for this. To this extent, the true number of successful students is probably understated by Group (a), but the possible deficit is small enough to ignore.

The analysis which follows is concerned with the differences between these two groups in terms of the various factors enumerated above. First, each factor is considered separately. Those found to be differently represented in the two groups have been examined later, in greater detail, because of possible interaction between them so as to isolate their independent contributions to the overall differences.

\section{LENGTH OF SERVICE}

Of the students joining Hospital $\mathrm{A}$ in the 3 years 1951-1953, 16 per cent. left by the end of the first year, compared with 17,22 , and 14 per cent. respectively at Hospitals $B, C$, and $D$. By the end of the second year, the total percentage of students who had left was 22 at A, 27 at B, 32 at C, and 26 at $D$. Thus, at each training school, a greater proportion left during the first year than during the second, though at $\mathrm{D}$ the difference was small. In Table I, annual wastage is related to the number of students starting each year's course. 3 The expected number has been calculated on the $\stackrel{\square}{\circ}$ null hypothesis, namely, that there is no difference in wastage rates between the hospitals for each year $\stackrel{\vec{S}}{\stackrel{9}{9}}$ of training.

The number leaving during each year of training did not differ significantly (the conventional level of $P=0.05$ is used throughout) between the hospitals. The differences were most marked in the third year, but this is understandable because of the number of nurses leaving to take up other posts on completion of their training.

\section{Age ON ENTRY}

An age peak at 18 years characteristic of recruits at $\mathbf{A}$ was not found in the other three hospitals, where 17-year-olds featured more prominently. Older students (i.e. aged 25 and over) were commoner at $B$ and $C$ than at $A$ and $D$. The average age of the students at entry is given in Table II (opposite).

At $\mathrm{D}$, the mean age of all students was significantly less than for those at any of the other three training centres. The students at $A$ were, on average, signi ficantly younger than those at $B$ and $C$, but there were no differences between the latter two schools

TABLE I

NUMBER OF STUDENTS AT BEGINNING OF EACH YEAR OF TRAINING, 1951-53, NUMBER LEAVING AND EXPECTED NUMBER LEAVING ON THE NULL HYPOTHESIS, BY TRAINING SCHOOL

\begin{tabular}{|c|c|c|c|c|c|c|}
\hline \multirow{2}{*}{ Year of Training } & \multirow{2}{*}{$\begin{array}{c}\text { Training } \\
\text { School }\end{array}$} & \multirow{2}{*}{$\begin{array}{l}\text { Number } \\
\text { Starting }\end{array}$} & \multirow{2}{*}{$\begin{array}{c}\text { Percentage } \\
\text { Leaving }\end{array}$} & \multicolumn{2}{|c|}{ Number Leaving } & \multirow{2}{*}{ Significance } \\
\hline & & & & Observed & Expected & \\
\hline \multirow[t]{2}{*}{$1 \mathrm{st}$} & $\begin{array}{l}\mathbf{A} \\
\mathbf{B} \\
\mathbf{C} \\
\mathbf{D}\end{array}$ & $\begin{array}{r}379 \\
175 \\
91 \\
58\end{array}$ & $\begin{array}{l}16.1 \\
17.1 \\
22.0 \\
13.8\end{array}$ & $\begin{array}{l}61 \\
30 \\
20 \\
8\end{array}$ & $\begin{aligned} 64 \cdot 16 \\
29 \cdot 62 \\
15 \cdot 41 \\
9 \cdot 82\end{aligned}$ & \multirow[t]{2}{*}{$\begin{array}{l}x^{2}=1.86 \\
\text { D.F. }=3 \\
0.70>P>0.50\end{array}$} \\
\hline & Total & 703 & 16.9 & 119 & 119 & \\
\hline \multirow[t]{2}{*}{ 2nd } & $\begin{array}{l}\mathbf{A} \\
\mathbf{B} \\
\mathbf{C} \\
\mathbf{D}\end{array}$ & $\begin{array}{r}318 \\
145 \\
71 \\
50\end{array}$ & $\begin{array}{r}7 \cdot 5 \\
11.7 \\
12 \cdot 7 \\
14.0\end{array}$ & $\left.\begin{array}{c}24 \\
17 \\
9 \\
7\end{array}\right\}$ & $\left.\begin{array}{c}31 \cdot 04 \\
14.15 \\
6 \cdot 93 \\
4 \cdot 88\end{array}\right\}$ & \multirow[t]{2}{*}{$\begin{array}{l}\chi^{2}=3 \cdot 66 \\
\text { D.F. }=2 \\
0 \cdot 20>P>0 \cdot 10\end{array}$} \\
\hline & Total & 584 & $9 \cdot 8$ & 57 & 57 & \\
\hline \multirow[t]{2}{*}{ *3rd } & $\begin{array}{l}\mathbf{A} \\
\mathbf{B} \\
\mathbf{C} \\
\mathbf{D}\end{array}$ & $\begin{array}{r}294 \\
128 \\
62 \\
43\end{array}$ & $\begin{array}{l}52.4 \\
53.9 \\
38.7 \\
25.6\end{array}$ & $\begin{array}{r}154 \\
69 \\
24 \\
11\end{array}$ & $\begin{array}{r}143 \cdot 94 \\
62.67 \\
30 \cdot 36 \\
21 \cdot 05\end{array}$ & \multirow[t]{2}{*}{$\begin{array}{l}x^{2}=7 \cdot 47 \\
\text { D.F. }=3 \\
0 \cdot 10>P>0.05\end{array}$} \\
\hline & Total & 527 & $49 \cdot 0$ & 258 & 258 & \\
\hline \multirow[t]{2}{*}{ All Years } & $\begin{array}{l}\mathbf{A} \\
\mathbf{B} \\
\mathbf{C} \\
\mathbf{D}\end{array}$ & $\begin{array}{r}379 \\
175 \\
91 \\
58\end{array}$ & $\begin{array}{l}63 \cdot 1 \\
66 \cdot 3 \\
58 \cdot 2 \\
44 \cdot 8\end{array}$ & $\begin{array}{r}239 \\
116 \\
53 \\
26\end{array}$ & $\begin{array}{r}233.99 \\
108.05 \\
56 \cdot 18 \\
35.81\end{array}$ & \multirow[t]{2}{*}{$\begin{array}{l}\begin{array}{l}\chi^{2}=3 \cdot 56 \\
\text { D.F. } \\
0.50\end{array}=3>0.30\end{array}$} \\
\hline & Total & 703 & $61 \cdot 7$ & 434 & 434 & \\
\hline \multicolumn{7}{|c|}{ Brackets indicate grouping of $\chi^{2}$ test. } \\
\hline
\end{tabular}


TABLE II

MEAN AGE (WITH STANDARD ERROR) OF STUDENTS ON JOINING TRAINING SCHOOLS DURING THE THREE YEARS, 1951-1953

\begin{tabular}{|c|c|c|c|}
\hline $\begin{array}{l}\text { Training } \\
\text { School }\end{array}$ & $\begin{array}{l}\text { Student } \\
\text { Group }\end{array}$ & $\begin{array}{l}\text { Number of } \\
\text { Students }\end{array}$ & $\begin{array}{l}\text { Mean Age (yrs) with } \\
\text { Standard Error }\end{array}$ \\
\hline \multirow[t]{2}{*}{$\mathbf{A}$} & (a) & $\begin{array}{l}262 \\
117\end{array}$ & $\begin{array}{l}19.4 \pm 0.14 \\
19.4 \pm 0.17\end{array}$ \\
\hline & Total ... & 379 & $19 \cdot 4 \pm 0 \cdot 10$ \\
\hline \multirow[t]{2}{*}{ B } & (a) & $\begin{array}{r}110 \\
65\end{array}$ & $\begin{array}{l}20.8 \pm 0.48 \\
20.7 \pm 0.52\end{array}$ \\
\hline & Total . . & 175 & $20.8 \pm 0.36$ \\
\hline \multirow[t]{2}{*}{ C } & (a) & $\begin{array}{l}42 \\
49\end{array}$ & $\begin{array}{l}21 \cdot 6 \pm 0.71 \\
20.1 \pm 0.45\end{array}$ \\
\hline & Total $\ldots$ & 91 & $20.8 \pm 0.41$ \\
\hline \multirow[t]{2}{*}{ D } & (a) & $\begin{array}{r}40 \\
* 17\end{array}$ & $\begin{array}{l}18.7 \pm 0.29 \\
17.9 \pm 0.19\end{array}$ \\
\hline & Total .. & $* 57$ & $18.5 \pm 0.22$ \\
\hline
\end{tabular}

(a) Successful students. (b) Unsuccessful students. Excluding one student whose age was not stated.

that could not easily have arisen by chance. Taking the successful students separately, the mean ages were significantly greater at $B$ and $C$ than at $A$ or $D$ : the difference between $A$ and $D$ was not significant. For the unsuccessful groups, the mean age of students at $\mathrm{D}$ was significantly lower than at any of the other hospitals and that of students at A significantly less than that of those at B.

In the individual schools, there was little difference between the average ages of the two groups at $\mathrm{A}$ and $B$. At C and D, however, the unsuccessful were, on average, younger by about a year than the successful students, but only at $\mathrm{D}$ was the difference significant.

It seems likely that age on entry may be a factor associated with success and it is again considered later.

\section{Educational Attainment Before EnTRy}

The only assessment made of the standard of education before entering the training school was the possession or otherwise of either the school, general, higher, or other certificate of education. Four-fifths of the students at A held one or more of these certificates, compared with 24 per cent. at B, 19 per cent. at $C$, and 29 per cent. at $D$.

Table III shows that, apart from $B$, there was no material difference in the educational level between the two groups.

It would seem that the possession of an education certificate does not confer an overwhelming advantage in training for nursing, but, in view of the difference at $\mathbf{B}$, this measure of education is reserved for re-consideration.

\section{SchoOl-Leaving Age}

From what has been said in the previous sections on education and age on joining, it might be inferred that the average age of students at $A$ on leaving the day school was somewhat higher than at the other hospitals. Very few of those joining at A had left school before 16 years of age, whereas several at the

TABLE III

NUMBER AND PERCENTAGE OF STUDENTS POSSESSING SCHOOL CERTIFICATES ON ENTERING TRAINING SCHOOLS DURING THE THREE YEARS, 1951-1953, BY TRAINING SCHOOL

\begin{tabular}{|c|c|c|c|c|c|c|c|}
\hline \multirow{2}{*}{ Training School } & \multirow{2}{*}{\multicolumn{2}{|c|}{$\begin{array}{l}\text { Student } \\
\text { Group }\end{array}$}} & \multicolumn{3}{|c|}{ Educational Status } & \multirow{2}{*}{$\begin{array}{l}\text { Percentage } \\
\text { with } \\
\text { Certificate }\end{array}$} & \multirow{2}{*}{$\begin{array}{c}\text { Test of } \\
\text { Significance } \\
\text { of Fourfold } \\
\text { Table (D.F. = 1) }\end{array}$} \\
\hline & & & Certificate & $\begin{array}{c}\text { No } \\
\text { Certificate }\end{array}$ & Total & & \\
\hline \multirow[t]{2}{*}{$\mathbf{A}$} & \multicolumn{2}{|c|}{$\begin{array}{l}(a) \\
(b)\end{array}$} & $\begin{array}{r}215 \\
89\end{array}$ & $\begin{array}{l}47 \\
28\end{array}$ & $\begin{array}{l}262 \\
117\end{array}$ & $\begin{array}{l}82 \cdot 1 \\
76 \cdot 1\end{array}$ & \multirow[t]{2}{*}{$\begin{array}{l}\chi^{2}=1.47 \\
0 \cdot 30>P>0.20\end{array}$} \\
\hline & Total & .. & 304 & 75 & 379 & $80 \cdot 2$ & \\
\hline \multirow[t]{2}{*}{ B } & \multicolumn{2}{|c|}{ (a) } & $\begin{array}{r}36 \\
6\end{array}$ & $\begin{array}{l}74 \\
59\end{array}$ & $\begin{array}{r}110 \\
65\end{array}$ & $\begin{array}{r}32 \cdot 7 \\
9 \cdot 2\end{array}$ & \multirow[t]{2}{*}{$\begin{array}{l}x^{2}=11 \cdot 11 \\
P<0.001\end{array}$} \\
\hline & Total & . & 42 & 133 & 175 & $24 \cdot 0$ & \\
\hline \multirow[t]{2}{*}{$\mathbf{C}$} & \multicolumn{2}{|c|}{ (a) } & $\begin{array}{l}8 \\
9\end{array}$ & 34 & 42 & $\begin{array}{l}19 \cdot 0 \\
18 \cdot 4\end{array}$ & \multirow[t]{2}{*}{$\begin{array}{l}\chi^{2}=0.03 \\
0.90>P>0.80\end{array}$} \\
\hline & Total & . & 17 & 74 & 91 & $18 \cdot 7$ & \\
\hline \multirow[t]{2}{*}{$\mathbf{D}$} & \multicolumn{2}{|c|}{$\left(\begin{array}{l}a) \\
(b)\end{array}\right.$} & $\begin{array}{r}13 \\
4\end{array}$ & $\begin{array}{l}27 \\
14\end{array}$ & $\begin{array}{l}40 \\
18\end{array}$ & $\begin{array}{l}32 \cdot 5 \\
22 \cdot 2\end{array}$ & \multirow[t]{2}{*}{$\begin{array}{l}x^{2}=0.23 \\
0.70>P>0.50\end{array}$} \\
\hline & Total & $\ldots$ & 17 & 41 & 58 & $29 \cdot 3$ & \\
\hline
\end{tabular}

(a) Successful students.

(b) Unsuccessful students. 
other training centres had done so. Table IV gives the average school-leaving age. For all students, the difference between the mean age on leaving school of the students at $\mathbf{A}$ was significantly greater than elsewhere, but at B, C, and D the mean ages were similar.

TABLE IV

MEAN AGE (WITH STANDARD ERROR) ON LEAVING DAYSCHOOL OF STUDENTS JOINING DURING THE THREE YEARS, 1951-1953, BY TRAINING SCHOOL

\begin{tabular}{|c|c|c|c|}
\hline $\begin{array}{l}\text { Training } \\
\text { School }\end{array}$ & $\begin{array}{l}\text { Student } \\
\text { Group }\end{array}$ & $\begin{array}{l}\text { Number of } \\
\text { Students* }\end{array}$ & $\begin{array}{l}\text { Mean Age (yrs) with } \\
\text { Standard Error }\end{array}$ \\
\hline \multirow[t]{2}{*}{ A } & (a) & $\begin{array}{l}260 \\
117\end{array}$ & $\begin{array}{l}17.3 \pm 0.05 \\
17.2 \pm 0.08\end{array}$ \\
\hline & Total .. & 377 & $17 \cdot 3 \pm 0.04$ \\
\hline \multirow[t]{2}{*}{ B } & (a) & $\begin{array}{r}104 \\
57 \\
\end{array}$ & $\begin{array}{l}16.3 \pm 0.11 \\
15.9 \pm 0.14\end{array}$ \\
\hline & Total .. & 161 & $16.1 \pm 0.08$ \\
\hline \multirow[t]{2}{*}{$\mathbf{C}$} & (a) & $\begin{array}{l}38 \\
46 \\
\end{array}$ & $\begin{array}{l}16.4 \pm 0.20 \\
16.3 \pm 0.19\end{array}$ \\
\hline & Total & 84 & $16.3 \pm 0.13$ \\
\hline \multirow[t]{2}{*}{ D } & (a) & $\begin{array}{r}38 \\
9\end{array}$ & $\begin{array}{l}16.1 \pm 0.14 \\
15.6 \pm 0.11\end{array}$ \\
\hline & Total .. & 47 & $16 \cdot 0 \pm 0.12$ \\
\hline
\end{tabular}

(a) Successful students. (b) Unsuccessful students.

* Excluding two at A, fourteen at B, seven at $C$ and eleven at D, whose age on leaving day-school was not stated.

There was no material difference between the average age of successful and unsuccessful students at $A$ and $C$. At $B$ and D, however, the successful students were approximately 6 months older than the unsuccessful, and this difference was greater than that which could easily have arisen by chance. Because of these differences, school-leaving age is considered again later.

\section{Social Class}

Student nurses as a group are included in the Registrar General's Social Class III. Of greater interest in the present survey, however, is the social class grouping of the students' parents which is based normally upon the fathers' occupation. Such information was available only at $\mathrm{A}$ and $\mathrm{D}$ and is analysed in Table V. Nearly all students at these two hospitals were drawn from the three upper social classes.

The information available suggests that successful and unsuccessful students do not have different social class backgrounds.

\section{NATIONALITY}

Hospitals $A$ and $D$ had a much higher proportion of British students than Hospitals B and C. Only ten ( 3 per cent.) of the 379 students at $A$, and three (5 per cent.) of the 59 students at $D$ were not British, and of these five at the former and one at the latter were Irish. In contrast, 49 ( 28 per cent.) of the 175 students at $B$ and eighteen ( 20 per cent.) of the 91 students at $\mathrm{C}$ were not British; of these, forty at $\mathrm{B}$ and five at $\mathrm{C}$ were Irish. The percentage of foreign students (i.e. students whose national language was not English) was not large ( 1 per cent. at A, 5 per cent. at B, 14 per cent. at $C$, and 3 per cent. at D).

Because of the small number of non - British students in the survey, an analysis by individua training school is not possible. Therefore, in Table VI, the four centres are combined.

TABLE VI

NATIONALITY OF STUDENTS JOINING THE TRAINING SCHOOLS DURING THE THREE YEARS, 1951-1953

\begin{tabular}{|c|c|c|c|c|c|c|c|}
\hline \multirow{2}{*}{ Nationality } & \multicolumn{3}{|c|}{$\begin{array}{l}\text { Number } \\
\text { Observed }\end{array}$} & \multicolumn{3}{|c|}{ Number Expected } & \multirow{2}{*}{$\begin{array}{l}\text { Percent- } \\
\text { age } \\
\text { Success- } \\
\text { ful }\end{array}$} \\
\hline & (a) & (b) & Total & (a) & (b) & Total & \\
\hline $\begin{array}{l}\text { British } \\
\text { Irish } \\
\begin{array}{l}\text { European } \\
\text { and Other }\end{array}\end{array}$ & $\begin{array}{r}404 \\
35 \\
15\end{array}$ & $\begin{array}{r}219 \\
16 \\
14\end{array}$ & $\begin{array}{r}623 \\
51 \\
29\end{array}$ & $\begin{array}{r}402 \cdot 33 \\
32 \cdot 94 \\
18 \cdot 73\end{array}$ & $\begin{array}{r}220.67 \\
18.06 \\
10.27\end{array}$ & $\begin{array}{r}623 \\
51 \\
29\end{array}$ & $\begin{array}{l}64 \cdot 8 \\
68 \cdot 6 \\
51 \cdot 7\end{array}$ \\
\hline Total & 454 & 249 & 703 & 454 & 249 & 703 & $64 \cdot 6$ \\
\hline
\end{tabular}

$x^{2}=2 \cdot 48$, D.F. $=2,0 \cdot 30>P>0 \cdot 20$

$\begin{array}{ll}\text { (a) Successful students. } & \text { (b) Unsuccessful students. }\end{array}$

TABLE V

SOCIAL CLASS OF PARENTS OF STUDENTS JOINING TRAINING SCHOOLS A AND D DURING THE THREE YEARS 1951-1953

\begin{tabular}{|c|c|c|c|c|c|c|}
\hline \multirow{2}{*}{$\begin{array}{l}\text { Training } \\
\text { School }\end{array}$} & \multirow{2}{*}{ Social Class } & \multicolumn{3}{|c|}{ Number of Students } & \multirow{2}{*}{$\begin{array}{l}\text { Percentage } \\
\text { Successful }\end{array}$} & \multirow{2}{*}{$\begin{array}{l}\text { Test of Significance } \\
\text { of Fourfold Table } \\
\text { (D.F.=1) }\end{array}$} \\
\hline & & Successful & Unsuccessful & Total & & \\
\hline \multirow[t]{2}{*}{$\mathbf{A}$} & $\begin{array}{l}\text { I and II } \ddot{~} \quad \ldots \\
\text { III, IV and } v \quad \ldots\end{array}$ & $\begin{array}{l}140 \\
104\end{array}$ & $\begin{array}{l}72 \\
42\end{array}$ & $\begin{array}{l}212 \\
146\end{array}$ & $\begin{array}{l}66 \cdot 0 \\
71 \cdot 2\end{array}$ & \multirow{2}{*}{$\begin{array}{l}x^{2}=0.85 \\
0.50>P>0.30\end{array}$} \\
\hline & Total $\quad .$. & 244 & 144 & 358 & $68 \cdot 2$ & \\
\hline \multirow[t]{2}{*}{ D } & $\begin{array}{l}\text { I and II . } \\
\text { III, IV and } v\end{array}$ & $\begin{array}{l}10 \\
24\end{array}$ & $\begin{array}{r}3 \\
14\end{array}$ & $\begin{array}{l}13 \\
38\end{array}$ & $\begin{array}{l}76 \cdot 9 \\
63 \cdot 2\end{array}$ & \multirow{2}{*}{$\begin{array}{l}\text { Exact } P \\
\text { Single tail }=0.29 \\
\text { Double tail }=0.50\end{array}$} \\
\hline & Total $\quad .$. & 34 & 17 & 51 & 66.6 & \\
\hline
\end{tabular}


The proportion of successful students was highest among Irish students and lowest among European and others, but the difference could easily have arisen by chance. As far as the present survey is concerned, nationality has little bearing on the outcome of training.

\section{SEASON OF ENTRY}

Season of entry reflects to a large extent the local arrangement of the schools. At Hospital A, the intake was fairly constant throughout the year, though there was a slight tendency for more students to be recruited in the Autumn and Winter months than in the Spring and Summer. At B, the smallest intake took place during the Summer; at other times the number joining did not vary greatly.

As already noted, the percentage of successful students was highest at $A$ and $D$ and lowest at $C$ and this pattern was maintained between the seasons. The overall distribution of students by season of entry is given in Table VII.
It can be concluded, therefore, that season of joining has no effect upon the final result.

\section{Pre-Nursing Course}

Except for Hospital A, very few students had attended a pre-nursing course. For this reason the analysis of this aspect (Table VIII) is confined to A alone.

The Table shows that the proportion of successful students was higher among those who had attended the pre-nursing course at the hospital than among those who had not for each year under review. For the three years combined, the difference was almost statistically significant. But as this only applies to Hospital A, it cannot conveniently be further considered.

\section{FACTORS INFLUENCING Results}

Of the seven variables examined (age on entry, educational attainment before entry, school-leaving

TABLE VII

NUMBER AND PERCENTAGE OF STUDENTS JOINING THE TRAINING SCHOOLS DURING THE THREE YEARS 1951-1953, BY SEASON OF JOINING

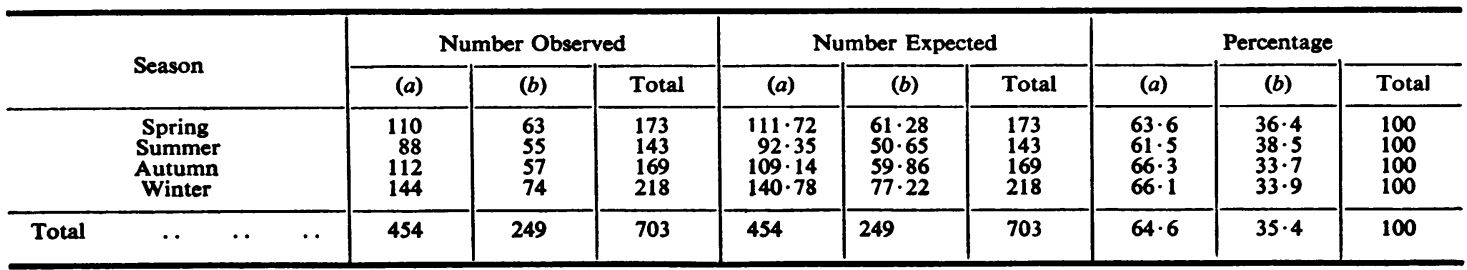

(b) Unsuccessful students.

TABLE VIII

STUDENTS JOINING TRAINING SCHOOL A DURING THE THREE YEARS 1951-1953, ANALYSED BY ATTENDANCE AT PRE-NURSING COURSE

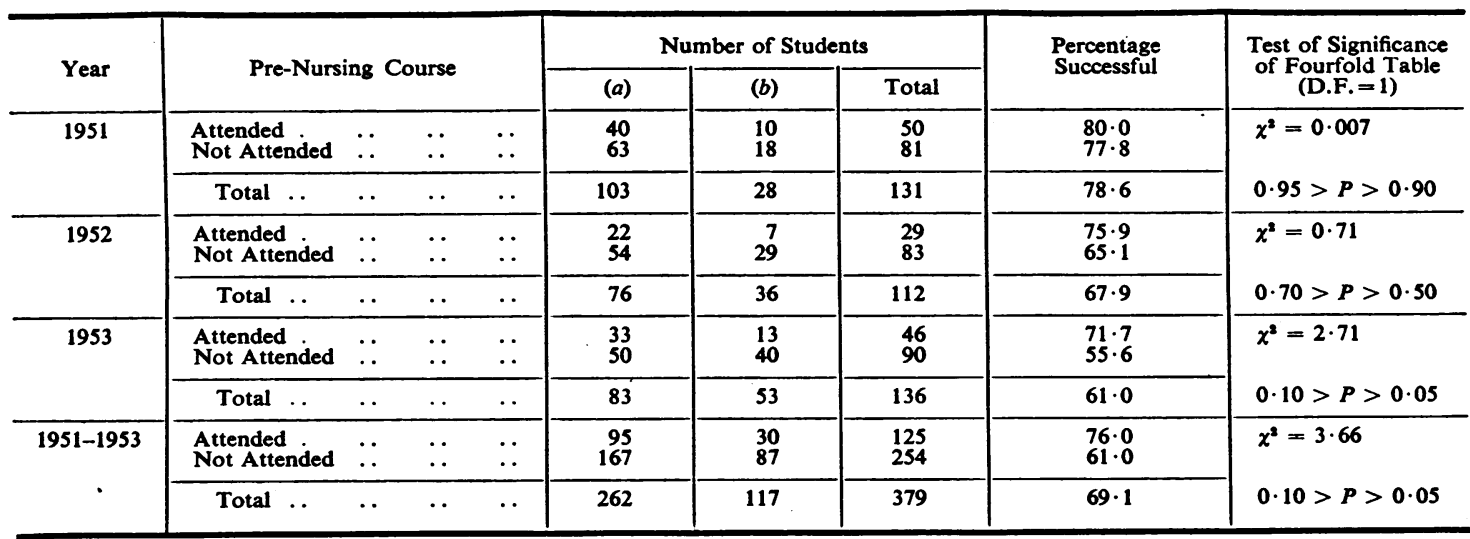


age, social class, nationality, season of entry, and pre-nursing course), three (age on entry, educational attainment before entry, and school-leaving age) require further consideration because of differences found between the two groups. The social class of parents, nationality, season of entry, and attendance at a pre-nursing course did not appear to have any significant bearing upon whether the students were successful or not. There was, however, a tendency for students who had attended the pre-nursing course at Hospital A to experience a higher proportion of successes.

To examine how far age on entry, school-leaving age, and educational attainment before entry influenced the proportion of successes the 669 students, for whom this information was completed, have been classified into eight groups identified by combinations of the dichotomies of these three factors. The eight groups and the success rate in each are shown in Table IX.

The Table shows that there were significant differences between the eight groups, but this was largely due to the relatively low success rate among students who had left school at 16 years of age or under without a school certificate. Although, among those who left school later, the success rate of those with certificates were also higher than that of those without, the differences do not reach the level of technical significance. It is of interest to note that the highest success rate, 76.4 per cent., occurred in those aged 19 or over on entry who had left school with a certificate at 17 or 18 years of age. Little difference, however, was found between the success rate for this group and that for the equivalent group with no school certificates.

\section{Discussion AND Conclusions}

Remarkably few objective studies have been made of the results of training student nurses, though the need for research in the field was stressed by the Ministry Working Party on the Recruitment and Training of Nurses (1947). The Working Party estimated that approximately 17 per cent. of nurses entered training before reaching the age of 18 years. The most popular year for entry appeared to be the nineteenth. Altogether half of the nurses entered before they reached the age of 20 and a half afterwards. One-third entered between their 20th and 26th birthdays, and 14 per cent. after reaching the age of 26. In the present survey, one-fifth of the students entered the training schools before their 18th birthday, which was a slightly higher proportion than was found by the Working Party. The most popular age for joining was 18 years for the four training schools combined, though at the three non-teaching hospitals (B, C, and D), more students joined at 17 than at any other single age. On the other hand, the proportion of older students in the present survey was lower (11 per cent. of the students in the present survey entered at 25 years or over). Thus, on the whole, the average age of the students in this survey tended to be less than that estimated by the Working Party.

Nearly half of the total number of nurses in hospitals, including students, in the Working Party's investigation, had received full-time education up to the age of 14 or 15 only. Another 30 per cent. had received some further education, part-time or fulltime, without reaching school certificate standard, while one in every six had reached school certificate or matriculation standard but had not proceeded

TABLE IX

RESULTS OF TRAINING CLASSIFIED BY AGE ON ENTRY, AGE ON LEAVING SCHOOL AND EDUCATIONAL STATUS FOR ALL STUDENTS JOINING FOUR HOSPITALS DURING THE THREE YEARS 1951-1953 (EXCLUDES 34 STUDENTS FOR WHOM DETAILS WERE NOT COMPLETE)

\begin{tabular}{|c|c|c|c|c|c|c|c|c|}
\hline \multirow{2}{*}{$\begin{array}{c}\text { Age on } \\
\text { Entry } \\
\text { (yrs) }\end{array}$} & \multirow{2}{*}{$\begin{array}{l}\text { School- } \\
\text { Leaving } \\
\text { Age (yrs) }\end{array}$} & \multirow{2}{*}{\multicolumn{2}{|c|}{ Educational Status }} & \multicolumn{3}{|c|}{ Number of Students } & \multirow{2}{*}{$\begin{array}{l}\text { Percentage } \\
\text { Successful }\end{array}$} & \multirow{2}{*}{ Contribution to $\chi^{2}$} \\
\hline & & & & Successful & $\begin{array}{c}\text { Not } \\
\text { Successful }\end{array}$ & Total & & \\
\hline \multirow{2}{*}{17,18} & $14,15,16$ & $\begin{array}{l}\text { Certificate } \\
\text { No Certificate }\end{array}$ & $\cdots$ & $\begin{array}{l}46 \\
67\end{array}$ & $\begin{array}{l}18 \\
56\end{array}$ & $\begin{array}{r}64 \\
123\end{array}$ & $\begin{array}{l}71 \cdot 9 \\
54 \cdot 5\end{array}$ & $\begin{array}{l}1 \cdot 06 \\
6 \cdot 97\end{array}$ \\
\hline & 17,18 & $\begin{array}{l}\text { Certificate } \\
\text { No Certificate }\end{array}$ & 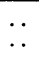 & $\begin{array}{r}138 \\
15\end{array}$ & $\begin{array}{r}55 \\
9\end{array}$ & $\begin{array}{r}193 \\
24\end{array}$ & $\begin{array}{l}71 \cdot 5 \\
62 \cdot 5\end{array}$ & $\begin{array}{l}2 \cdot 82 \\
0 \cdot 11\end{array}$ \\
\hline \multirow{2}{*}{$19+$} & $14,15,16$ & $\begin{array}{l}\text { Certificate } \\
\text { No Certificate }\end{array}$ & $\begin{array}{l}\cdots \\
\cdots\end{array}$ & $\begin{array}{l}26 \\
68\end{array}$ & $\begin{array}{l}13 \\
52\end{array}$ & $\begin{array}{r}39 \\
120\end{array}$ & $\begin{array}{l}66 \cdot 7 \\
56 \cdot 7\end{array}$ & $\begin{array}{l}0 \cdot 01 \\
4 \cdot 42\end{array}$ \\
\hline & $17,18,19$ & $\begin{array}{l}\text { Certificate } \\
\text { No Certificate }\end{array}$ & $\ddot{*}$ & $\begin{array}{l}55 \\
25\end{array}$ & $\begin{array}{r}17 \\
9\end{array}$ & $\begin{array}{l}72 \\
34\end{array}$ & $\begin{array}{l}76 \cdot 4 \\
73 \cdot 5\end{array}$ & $\begin{array}{l}3 \cdot 61 \\
0 \cdot 91\end{array}$ \\
\hline Total & $\cdots$ & $\ldots$ & $\ldots$ & 440 & 229 & 669 & $65 \cdot 8$ & \\
\hline
\end{tabular}


further. This contrasts sharply with the results of the present inquiry, which shows that four-fifths of the students had received full-time education beyond 15 years and that almost half of them held some form of school certificate.

Cross and Hall (1954) found that, for general hospitals in the Birmingham region, the proportion of successes was lowest at ages under 18 years. The present findings do not show the same marked discrepancies for students under 18 years. In fact, the 17-year-old students as a group compared very favourably with their older contemporaries as Table $\mathrm{X}$ shows.

\section{TABLE X}

COMPARISON OF RESULTS OF BIRMINGHAM SURVEY BASED ON STUDENTS ENTERING TRAINING SCHOOLS OF GENERAL HOSPITALS IN 1946 (CROSS AND HALL, 1954) AND OXFORD SURVEY OF STUDENTS JOINING FOUR GENERAL HOSPITALS DURING 1951-1953

\begin{tabular}{|c|c|c|c|c|}
\hline \multirow{2}{*}{$\begin{array}{c}\text { Age on Entry } \\
\text { to Training } \\
\text { School } \\
\text { (yrs) }\end{array}$} & \multicolumn{2}{|c|}{ Birmingham Survey } & \multicolumn{2}{|c|}{ Oxford Survey } \\
\hline & $\begin{array}{c}\text { Total } \\
\text { Students }\end{array}$ & $\begin{array}{l}\text { Percentage } \\
\text { Successful }\end{array}$ & $\begin{array}{c}\text { Total } \\
\text { Students }\end{array}$ & $\begin{array}{l}\text { Percentage } \\
\text { Successful }\end{array}$ \\
\hline $\begin{array}{l}\text { Under } 18 \\
18- \\
19- \\
20-24 \\
25+\end{array}$ & $\begin{array}{l}154 \\
207 \\
117 \\
274 \\
102\end{array}$ & $\begin{array}{l}39 \cdot 0 \\
51 \cdot 7 \\
46 \cdot 2 \\
48 \cdot 2 \\
52 \cdot 9\end{array}$ & $\begin{array}{r}145 \\
274 \\
95 \\
136 \\
52\end{array}$ & $\begin{array}{l}67 \cdot 6 \\
62 \cdot 4 \\
65 \cdot 3 \\
65 \cdot 4 \\
65 \cdot 4\end{array}$ \\
\hline Total $^{*} \quad \ldots$ & 854 & $47 \cdot 7$ & 702 & $64 \cdot 7$ \\
\hline
\end{tabular}

* Excludes students whose ages were unknown.

The two surveys differ markedly both in regard to overall results and also in regard to ages. This may be due to the fact that the Birmingham survey was carried out in the immediate post-war years when working conditions were rather unstable, to differences in the type of area and the quality of the recruits, or to differences in the composition of the samples. Of these, the time of conducting the survey seems to be the most likely explanation of the differences. By the Nurses' Rules Approval Instrument of 1951 (General Nursing Council, 1952), the minimum age for entering nursetraining schools after August 1, 1952, was fixed at 18 years, so that the number of 17 -year-old recruits declined rapidly after 1952 at all four hospitals surveyed.

As might be expected, there is no clear-cut division between successful and unsuccessful students. An examination of the three most important variables (age on entry, age on leaving school, and educational attainment before entry) shows that, among comparable groups of students, the possession of a school certificate is likely to make the most difference to success in the group entering training and leaving school comparatively early. For other students a school certificate is an advantage, though not significantly so. The importance of an education certificate appears to diminish as the school-leaving age increases. This suggests that perhaps the interim period between leaving a day school and joining a training school is worth special consideration.

For practical purposes the present analysis indicates that the worst results are obtained by students who left school early without a school certificate irrespective of the age at which they entered the training school.

\section{SUMmaRY}

Successful and unsuccessful student nurses who joined four general hospital training schools in the Oxford region during the calendar years 1951-1953 inclusive have been analysed according to their final result, length of service, age on entry, educational attainment before entry, school-leaving age, social class of parents (for two hospitals only), nationality, season of entry, and attendance at a preliminary training course (for one hospital only).

No clear distinction emerged between the successful and unsuccessful students, but the practical conclusion drawn from the analysis is that the success rate was lowest among students who left school early with no education certificate, irrespective of the age at which they entered the training school.

Thanks are due to the Matrons of the four hospitals for supplying the basic data. I am also indebted to Dr. E. A. Cheeseman, of the Department of Social and Preventive Medicine, the Queen's University, Belfast, for considerable help and advice in preparing this paper.

\section{REFERENCES}

Barr, A., James, I., and Smith, H. M. V. (1957). Monthly Bull. Min. Hith, 16, 94.

Cross, K. W., and Hall, D. L. A. (1954). Brit. J. prev. soc. Med., 8, 70 General Nursing Council and Ministry of Health (1952). "The Nurses" Rules, Approval Instrument, 1951". Statutory Instruments, 1951, vol. 2, p. 105. No. 1372, H.M.S.O., London.

Ministry of Health, Department of Health for Scotland, and Ministry of Labour and National Service (1947). "Report of the Working
Party on the Recruitment and Training of Nurses". H.M.S.O., London. 